\title{
MAGEA10 Gene
}

National Cancer Institute

\section{Source}

National Cancer Institute. MAGEA10 Gene. NCI Thesaurus. Code C104496.

This gene may be involved in tumor transformation. 